\title{
Electropolishing of Metallic Surfaces and the Factors Influencing on the Limiting Current
}

\author{
Abdel-Moneim M. Ahmed, Mervette El Batouti" and Said M. Said Khelil \\ Chemistry Department, Faculty of Science, Alexandria University, Egypt
}

Received 11 March 2015; accepted 20 April 2015

\begin{abstract}
Anodic limiting currents were measured in an unstirred divided cell at an inclined small scale anode using a large scale cathode with angles of inclination from vertical axis as 45, 60 and $75^{\circ}$. Anode heights (II) vary from $1 \mathrm{~cm}$ to $6 \mathrm{~cm}$ and phosphoric acid concentration from 6 to 10 moles.

Limiting currents for electropolishing of copper were between 5 and $58 \mathrm{~mA} . \mathrm{cm}^{-2}$ depending on the operating conditions.

A general correlation of data of all inclinations was obtained using the equation:

$$
\mathrm{I}=28.57\left(\Theta^{0.520} . \mathrm{C}^{-0.89} \cdot \mathrm{H}^{-0.91}\right)
$$

with an average deviation of $\pm 4 \%$.

Keywords: Limiting current, electropolishing, metallic surfaces.

\section{Introduction}

Electropolishing has been used for various purposes in research and industry for many years. The approach formulation of the electropolishing solution in EP conditions and the process application itself were and are still the subject of numerous trod secrets and patent [1-3].

The practical aspects of EP have been reviewed by Mohan et al. [4] whereas the most fundamental aspects are covered in a review by Landolt [5].

EP is ideal for several fields such as medical pharmaceutical, semi-conductor and food processing industries [6].

Much work has been done on the phenomenon of electropolishing since its discovery by Jaquet $[7,8]$, owing to its importance as a metal finishing process. A great deal of work has been directed to the study of the mechanism of

* Corresponding author. E-mail address: mervette_b@yahoo.com 
electropolishing as well as to establishing the optimum polishing conditions for different metals and alloys [9].

Mechanistic studies [9, 10] have revealed that electropolishing is a diffusioncontrolled process which takes place at the limiting current, which is attained most probably when the diffusion layer becomes saturated with $\mathrm{Cu}^{+2}[9,12]$.

Therefore, the value of the limiting current which determines the polishing rate depends on the rate of the mass transfer of $\mathrm{Cu}^{+2}$ from the diffusion layer to the bulk of the solution. The rate of the mass transfer depends on the relative movement of the anode and the electrolyte, the physical properties of the electrolyte, the temperature and the geometry of the anode. The present work is concerned with the study of the factors affecting the limiting current of the electropolishing of inclined copper sheets in unstirred phosphoric acid solution, where the transfer of $\mathrm{Cu}^{+2}$ from the anode surface to the bulk solution is mainly by diffusion and natural convection arising from density differences between the interfacial solution (saturated copper phosphate in $\mathrm{H}_{3} \mathrm{PO}_{4}$ ) and the bulk solution $\mathrm{H}_{3} \mathrm{PO}_{4}$.

Previous works on the factors affecting the limiting current have overlooked the effect of anode geometry deposit and its importance in determining the value of the limiting current. The aim of this work is to study the effect of inclination on the rate of electropolishing of small scale anode, using large scale cathode parallel electrode, by measuring the limiting current densities for deposition of copper in phosphoric acid solution using a divided cell.

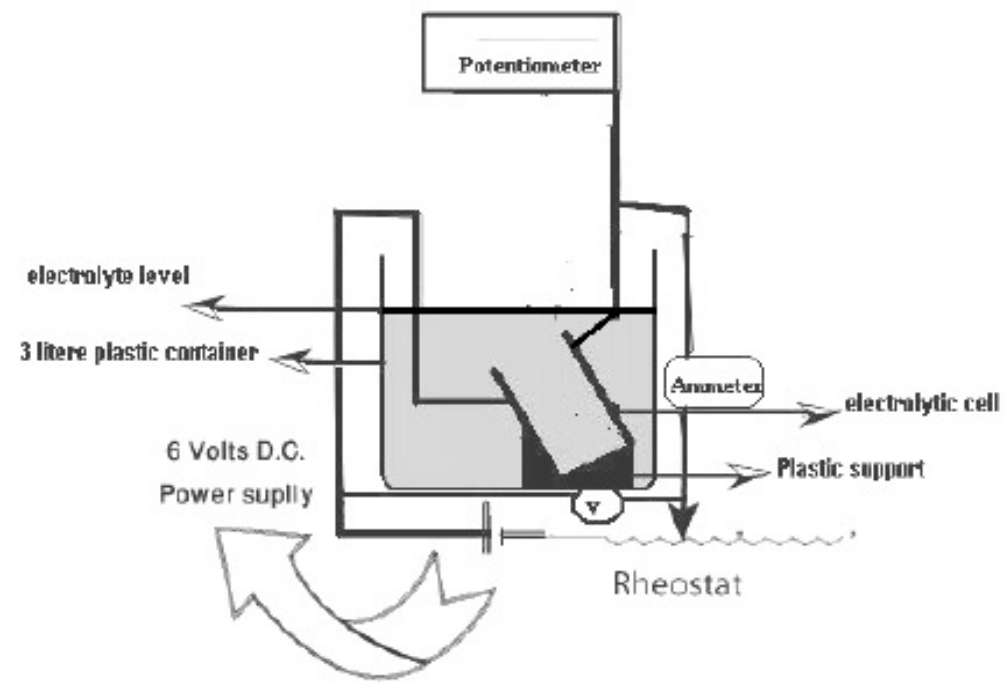

Figure 1. Cell and electrical circuit.

\section{Experimental technique}

Fig. (1) shows the cell and the electrical circuit used in the present work. The anode consists of a copper sheet of $1 \mathrm{~cm}$ wide and $10 \mathrm{~cm}$ high.

The cathode consists of a copper sheet of $10 \mathrm{~cm}$ wide and $18 \mathrm{~cm}$ high and also acted as a reference electrode by virtue of its high surface area compared with that of the anode. The anode height varies between 1 and $6 \mathrm{~cm}$. A rectangular Plexiglas electrolytic cell was used. The electrical circuit contains a $6 \mathrm{~V}$ DC power supply. In carrying out the experiment, the cathode reached the bottom of 
the cell whereas the free liquid was about $7 \mathrm{~cm}$ above the upper end of the cathode. A porous PVC diaphragm to prevent the stirring effect due to $\mathrm{H}_{2}$ bubbles was used.

Three inclined wax bases were used with an inclination in the cell at $45^{\circ}, 60^{\circ}$ and $75^{\circ}$; also, three concentrations of $\mathrm{H}_{3} \mathrm{PO}_{4}$, i.e., 6,8 and $10 \mathrm{M}$, prepared from A.R. grade $\mathrm{H}_{3} \mathrm{PO}_{4}$ and distilled water were used.

Polarization curves from which the limiting currents were determined were plotted by increasing the applied current stepwise and measuring the corresponding steady state potential; 2 minutes were allowed to reach the steady state potential.

Before each run, the back part of the anode was insulated with polystyrene lacquer and the active surface of the anode was polished with fine emery paper, degreased with trichloroethylene, washed with alcohol and finally rinsed in distilled water.

Table 1. Limiting current at different conditions.

\begin{tabular}{|c|c|c|c|c|}
\hline \multirow{3}{*}{$\begin{array}{c}\boldsymbol{\theta} \\
\text { degree }\end{array}$} & \multirow{3}{*}{$\begin{array}{c}\mathbf{H} \\
(\mathbf{c m})\end{array}$} & \multicolumn{3}{|c|}{$\mathrm{C}\left(\mathrm{mol} . \mathrm{L}^{-1}\right)$} \\
\hline & & 6 & 8 & 10 \\
\hline & & \multicolumn{3}{|c|}{ I $\left(\mathbf{m A . c m}{ }^{-2}\right)$} \\
\hline \multirow{4}{*}{$15^{\circ}$} & 1 & 25 & 22 & 20 \\
\hline & 2 & 16 & 15 & 12 \\
\hline & 4 & 10 & 9 & 6.5 \\
\hline & 6 & 3 & 5 & 4.3 \\
\hline \multirow{4}{*}{$30^{\circ}$} & 1 & 30 & 25 & 22 \\
\hline & 2 & 20 & 16 & 14 \\
\hline & 4 & 13 & 10 & 7 \\
\hline & 6 & 7 & 8 & 4.5 \\
\hline \multirow{4}{*}{$45^{\circ}$} & 1 & 40.0 & 32.0 & 28.0 \\
\hline & 2 & 21.0 & 20.0 & 16.0 \\
\hline & 4 & 15.0 & 11.0 & 7.5 \\
\hline & 6 & 8.0 & 8.3 & 5.0 \\
\hline \multirow{4}{*}{$60^{\circ}$} & 1 & 43.0 & 34.0 & 30.0 \\
\hline & 2 & 26.0 & 18.0 & 17.0 \\
\hline & 4 & 13.5 & 12.0 & 8.0 \\
\hline & 6 & 9.3 & 8.3 & 5.5 \\
\hline \multirow{4}{*}{$75^{\circ}$} & 1 & 56.0 & 40.0 & 32.0 \\
\hline & 2 & 27.0 & 20.0 & 17.5 \\
\hline & 4 & 14.0 & 11.0 & 8.5 \\
\hline & 6 & 10.3 & 8.0 & 6.0 \\
\hline \multirow{4}{*}{$90^{\circ}$} & 1 & 58.0 & 43.0 & 34.0 \\
\hline & 2 & 27.0 & 21.0 & 18.0 \\
\hline & 4 & 15.0 & 10.3 & 9.0 \\
\hline & 6 & 11.3 & 8.5 & 7.0 \\
\hline
\end{tabular}

\section{Results and discussion}

The measurements to get the limiting current at different conditions, which are the electrode's angle of inclination, the electrode height and $\mathrm{H}_{3} \mathrm{PO}_{4}$ concentration, were carried out and given in Table (1). Fig. (2) shows a set of typical current-potential curves obtained at different angles.

This figure shows that the limiting current increases with increasing the angle of 
inclination from 45-90x (Tables2 and 3), and Fig. (3) shows that it can be related to the angle of inclination by the equation:

$$
\mathrm{I} \alpha \Theta^{0.526}
$$

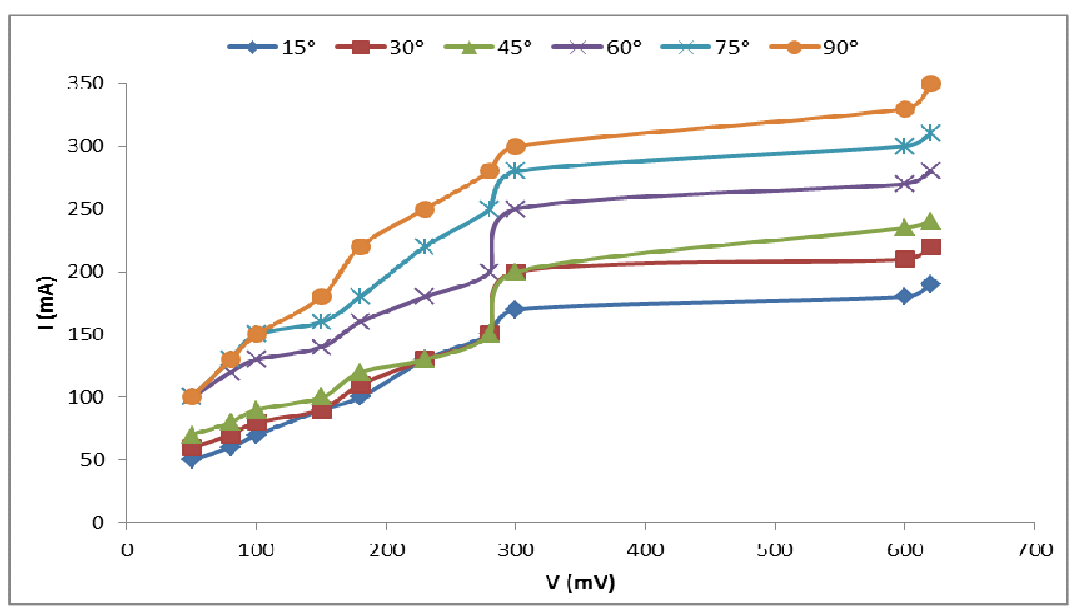

Figure 2. Current - potential curves at different angles.

Table 2. Limiting current at different height, concentration $6 \mathrm{M} \mathrm{H}_{3} \mathrm{PO}_{4}$ and angle $60^{\circ}$.

\begin{tabular}{|c|c|c|c|c|}
\hline Height $(\mathbf{c m})$ & $\mathbf{1}$ & $\mathbf{2}$ & $\mathbf{4}$ & $\mathbf{6}$ \\
\hline $\mathbf{I}_{\mathbf{l}}\left(\mathbf{m A} \mathbf{A} \cdot \mathbf{c m}^{-\mathbf{2}}\right)$ & 43 & 26 & 13.5 & 9.3 \\
\hline
\end{tabular}

Table 3. Limiting current at different angle of rotation at $6 \mathrm{M} \mathrm{H}_{3} \mathrm{PO}_{4}$ and $1 \mathrm{~cm}$ height.

\begin{tabular}{|c|c|c|c|c|c|c|}
\hline $\boldsymbol{\theta}$ & 15 & 30 & 45 & 60 & 75 & 90 \\
\hline$I_{1}\left(\mathrm{~mA} . \mathrm{cm}^{-2}\right)$ & 25 & 30 & 40 & 43 & 56 & 58 \\
\hline
\end{tabular}

Fig. 4 shows that the limiting current decreases with $\mathrm{H}_{3} \mathrm{PO}_{4}$ concentration within the range studied $(6-10 \mathrm{M})$ (Table 4$)$. This is in agreement with the finding of other authors who worked within the same range of concentration using other anode geometries [13-16] and can be attributed to the increase in solution viscosity and the consequent decrease in $\mathrm{Cu}^{+2}$ diffusibility.

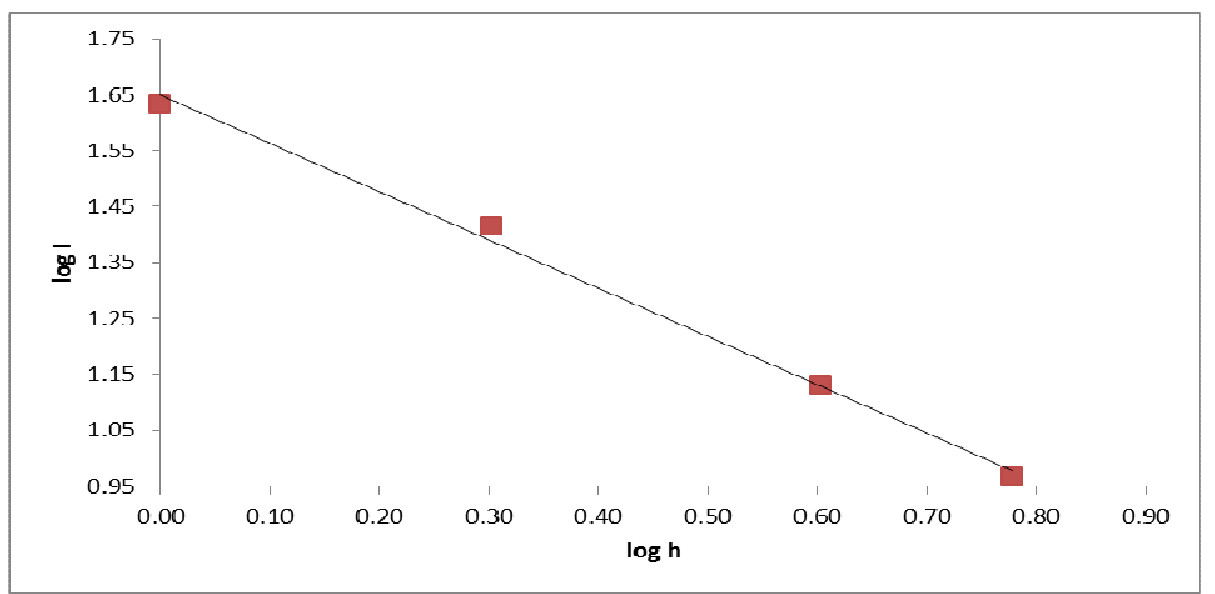

Figure 3. Relation between $\log I$ and $\log \mathrm{h}$. 
The effect of $\mathrm{H}_{3} \mathrm{PO}_{4}$ concentration on [17] the limiting current can be represented by the equation:

$$
\mathrm{I} \alpha \mathrm{C}^{-0.889}
$$

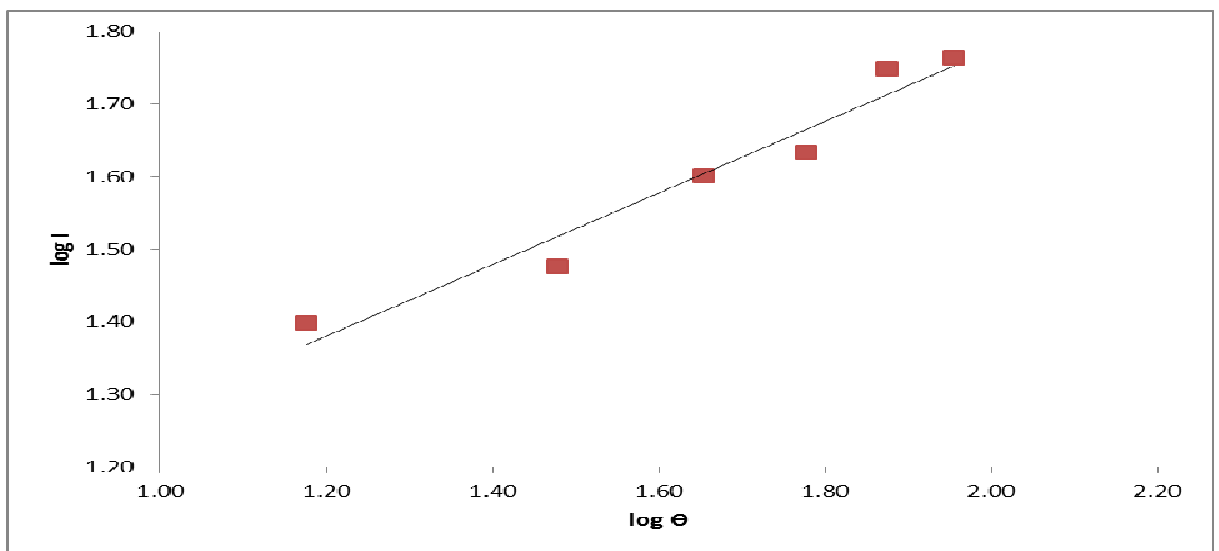

Figure 4. Relation between $\log I$ and $\log \Theta$.

Table 4. Limiting current at different $\mathrm{H}_{3} \mathrm{PO}_{4}$ concentration at angle $45^{\circ}$ and height $1 \mathrm{~cm}$.

\begin{tabular}{|c|c|c|c|}
\hline $\mathbf{C}$ of $\mathbf{H}_{\mathbf{3}} \mathbf{P O}_{\mathbf{4}}$, mole & $\mathbf{6}$ & $\mathbf{8}$ & $\mathbf{1 0}$ \\
\hline $\mathbf{I}_{\mathbf{l}}\left(\mathbf{m A} \cdot \mathbf{c m}^{-2}\right)$ & 40 & 32 & 28 \\
\hline
\end{tabular}

Fig. 5 shows that the limiting current decreases with increasing the electrode height; this agrees with the prediction of the hydrodynamic boundary layer theory $[18,19]$ according to which the diffusion layer thickness increases with increasing the electrode height. This figure shows that the limiting current can be related to the electrode height by the equation:

$$
\mathrm{I} \alpha \mathrm{H}^{-0.91}
$$

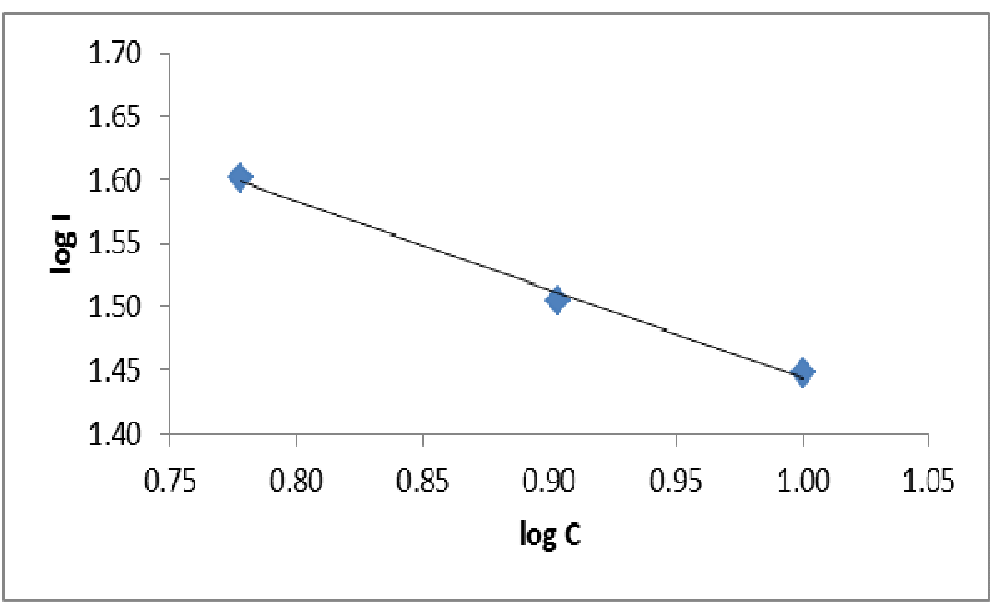

Figure 5. Relation between $\log I$ and $\log \mathrm{C}$. 
There is an overall correlation between the limiting current and the governing variables; the data can be represented by the equation:

$$
\mathrm{I}=28.57\left(\Theta^{0.520} \cdot \mathrm{C}^{-0.889} \cdot \mathrm{H}^{-0.909}\right)
$$

with an average deviation of $\pm 4 \%$.

\section{References}

1. Reid JD. US Patent. November; 2003.

2. Chandles WD. US Patent. June; 2003.

3. Taha AA, Ahmed AM, Abdel Rahman HH, et al. Appl Surf Sci. 2013;277:155.

4. Mohn S, Kanagari D, Sindhuja R, et al. Trans Inst Metal Finish. 2001;79:141.

5. Landoll D. Electroch. Acta. 1987;32:1.

6. Awad AM, Chazy EA, Abo El-Emin SA et al. Surf Coat Technol. 2012;206:3165.

7. Jaquet PA. Nature. 1935;133:1076.

8. Jaquet PA. Trans Electrochem Soc. 1936;69:629.

9. Tegart WJMcG. The electrolytic and chemical polishing of metals. London: Pergamon Press; 1959.

10. Elmore WC. J Appl Phys. 1934;10:724.

11. Edwards J. J Electrochem Soc. 1953;100:189C.

12. Zembimp Z, Michalik W. Bull Acad Pol Sci. 1957;1115:1073.

13. Gabe DR. Corros Sci. 1972;12:113.

14. Honeycombe RWK, Hughan RRJ. Counc Sci Ind Res Aust. 1953;20:274.

15. Hickling, Higgins JK. Trans Inst Met Finish. 1953;29:274.

16. Hoor TP, Rothwell GP. Electrochim Acta. 1971;16:1477.

17. Fouad MG, Zin FN, Isrnail MI. Electrochim Acta. 1971;16:1477.

18. Ettel VA, Tilak B, Gendron AS. J Electrochem Soc. 1974;121:867.

19. Ibl N. Adv Electroch Electroch Eng. 1962;2:49. 